\title{
Re-organization of assessment during the educational emergency in primary and secondary teaching: an Italian case Andrea Tinterri, Maka Eradze ${ }^{* \star}$, Anna Dipace ${ }^{* \star *}$, Martina Fava ${ }^{* \star * *}$
}

\begin{abstract}
The educational crisis caused by the pandemic created an unprecedented need to reorganize teaching and learning processes, and the educational assessment became one of the thorniest issues in this rapid change; assessment reorganization entails layered complexities on micro, meso and macro levels. This research is contextualized in a larger digital ethnographic study of three different Italian teacher online communities, uncovering the experience from mixedmethods research. Following this research, a survey instrument was developed and launched. Current paper reports on the survey aiming to uncover the change in assessment practices during the educational emergency while reflecting on teachers' beliefs on the assessment, the use of remote assessment methods before and during the pandemic, and its re-organization. Findings suggest a significant reorganization of assessment during the COVID-19 educational emergency in all school orders. Through all school orders, teachers perceived a reduction in the importance of assessment during the pandemic and, consequently, used most assessment techniques significantly less than before. However, different methods changed differently, with oral examinations diminishing dramatically and increased use of closed-question quizzes.

Keywords: assessment; COVID-19; primary school; secondary school; distance learning; emergency remote teaching
\end{abstract}

First submission: 14/09/2021, accepted: 10/10/2021

Available online: $21 / 12 / 2021$

${ }^{*}$ Department of Education and Human Sciences, University of Modena and Reggio Emilia, Viale Antonio Allegri, 9, 42121 Reggio Emilia, Italy. E-mail: tinterri.andrea@gmail.com.

** Department of Humanities, literature, cultural heritage and education sciences, University of Foggia, Via Arpi 176, 71100, Italy. E-mail maka.eradze@unifg.it.

*** Department of Education and Human Sciences, University of Modena and Reggio Emilia, Viale Antonio Allegri, 9, 42121 Reggio Emilia, Italy. E-mail: anna.dipace@unifg.it.

**** Department of Education and Human Sciences, University of Modena and Reggio Emilia, Viale Antonio Allegri, 9, 42121 Reggio Emilia, Italy. E-mail: 214323@studenti.unimore.it.

Doi: $10.3280 /$ ess2-2021oa12520 


\section{Introduction}

The COVID-19 pandemic has changed the educational landscape in the short, mid and long term. The problem of the access to education has caused what we call an educational emergency (Eradze et al., 2021) which has become the first challenge, needing an immediate response. Such a response was the introduction of large-scale distance learning, or better, its temporary form Emergency Remote Teaching (Hodges et al., 2020). While the experiences have been very challenging for the teachers, as well as for learners causing problems such as so-called "zoom fatigue", sudden workload increase and stress, it has also introduced some opportunities, that have yet to be analysed and reflected on.

The challenge that the educational institutions have faced in the pandemic, was of an organisational nature - they had to respond to the challenge and quickly re-organize teaching and learning processes; one of the most challenging topics in the transition process has been the assessment. As some of the assessment practices, such as assessment for learning (Wiliam, 2011) and assessment of learning (Harlen, 2007) are often related to the assessment of the achieved outcomes and aligned with state curriculum, and in the disrupted context of the COVID-19 emergency, this factored in the difficulty of the assessment re-organization management. Furthermore, while other types of learning activities are more flexible to re-organisation, in the assessment processes, there are several issues that must be considered when reorganising: such as academic integrity and trust (Gamage et al., 2020) further complicated by use of technology-enhanced assessment - its tools and practices existed before the pandemic, but they have been adopted very quickly, without much planning ahead.

To understand the impact of this transition from different perspectives, some researchers have documented these experiences all over the world (Bozkurt et al., 2020) capturing experiences with ERT (Albó et al., 2020). Many have investigated questions such as teachers' attitudes (Giovannella et al., 2021), change in motivation and digital skills in the context of the forced transition (Beardsley et al., 2021), while also tried to identify potential teacher professional development opportunities in them (Albó et al., 2020; Luik \& Lepp, 2020). It is worth noting that the pandemic self-initiated professional learning networks through social media have been successfully used to support the teachers in the transition to ERT in different countries (i.e.,(Beardsley et al., 2021; Eradze et al., 2021; Johnson, 2020; Johnson et al., 2022; Luik \& Lepp, 2020). In the context of the current educational emergency, "teacher advice seeking on Twitter seemed to shift from serving immediate instructional needs 
to focussing on professional development and the creation of their own digital content" (Beardsley et al., 2021).

Some authors have conceptualized the COVID-19 educational crisis in three phases: disruption, transition and re-imagining, seeing opportunities of reorganization in the current emergency (Fullan et al., 2020). We consider the COVID-19 related disruptions and educational re-organisation processes worth exploring, especially in the light of the use of technologies (Eradze et al., 2021; Rapanta et al., 2021), we have examined the issue of assessment from the Italian perspective, starting from the ethnographic study of Italian teacher online communities (Eradze et al., 2021), which revealed significant assessment reorganization uncertainties and related re-organization opportunities emerging in the teacher peer-learning communities. As a result, we have created a survey to explore possible changes in the assessment practices in the context of the COVID-19 disruptions and shed light on some of the issues such as teachers' beliefs about the importance of assessment before and after the pandemic, the use of remote assessment before the pandemic, and assessment reorganization following the pandemic. This article reports on the results of the survey.

\section{Context and the background}

The evaluation act at school is an integral part of pedagogical planning. It accompanies and regulates the pedagogic action and supports the learning processes of the student. The initial or diagnostic evaluation, carried out at the beginning of a new teaching-learning process, serves to verify the starting level of the students, ascertaining the possession of the prerequisites and possibly preparing individualized reinforcement and remediation activities. The formative or intermediate assessment, understood as assessment for learning, is the one that takes place during the entire teaching-learning process. The goal is the improvement of the pedagogic action through a comparison between the perception that one has of a knowledge or competence and their effective verification; it can be carried out both by the teacher and by the student himself as a self-assessment process (Guasti, 2013).The final or summative assessment, considered assessment of learning, is carried out at the end of a teachinglearning process and serves to provide a conclusive balance, concerning both the results and progress of the student and the effectiveness of the didactic action (Guasti, 2013).

Evaluation has always represented a crucial and delicate moment in the life of the teacher, the student and the families; this moment has been made even more problematic by the situation by Covid-19 educational emergency. 
On February 11, 2020, the World Health Organization (WHO) announced the Covid-19 disease (Corona Virus Disease). Italy was the first European country to sanction the national lockdown and in the Italian territory schools were closed from 5 March 2020 until the end of the school year; this decision involved the replacement of face-to-face teaching with distance learning. The term "distance learning" is detected in the institutional documentation since the decree of the President of the Council of Ministers of 25 February 2020, further implementing provisions of the decree-law 23 February 2020, n. 6, containing urgent measures on the containment and management of the epidemiological emergency from Covid-19.

The suspension of all face-to-face teaching activities was ordered with the Prime Ministerial Decree of 4 March 2020, whose art. 1, paragraph 1 letter d) reiterated the suspension until 15 March 2020 of educational services for children and educational activities in schools of all levels, and letter g), imposed on school leaders to activate distance learning for the entire period of suspension of teaching activity in schools, also taking into account the specific needs of students with disabilities (Official Gazette, 2020). On March 6, 2020, the Ministry of Education, with Note 278 that recalled the DL of February 23, 2020 , specified the need to promote distance learning as an emergency not only in the "red zones" in Northern Italy where schools are closed, but throughout the national territory and reported the MIUR website dedicated to distance learning (https://www.istruzione.it/coronavirus/didattica-a-distanza.html) and the creation of a task force to support school requests (Ministry of Education, 2020a).

The mandatory nature of distance learning was also confirmed by the Prime Ministerial Decree of 8 March 2020 and prime ministerial decree of 9 March 2020 and was then reiterated by Legislative Decree no. 19 of 25 March 2020 (converted into Law no. 35 of 22 May 2020), which resumed the provisions of Legislative Decree no. 6/2020, or the right to order new extensions to the suspension of face-to-face teaching activities, based on art. 1, letter $\mathrm{p}$ ), with the possibility of carrying them out in remote mode for all schools of all levels (Official Gazette, 2020).

With the note prot. 388 of 17 March 2020, the MIUR provided the first indications on the operating methods for distance learning, which must:

- Provide for an interaction between teachers and students, in synchronous and asynchronous mode, and not be limited to the assignment of tasks or only to the transmission of materials without there being a preparation by the teachers and a return by the students.

- Seek a balance between teaching activities and moments of pause, in relation to the age of the students, redesigning traditional teaching in distance learning. 
- Promote student autonomy to minimize the support of their families.

- Continue the process of inclusion of pupils with disabilities.

- Respect the personalized didactic plan of the students with DSA or BES, who are generally favored in the use of technologies because they already use electronic instrumentation.

- Encourage interrelationship, collaboration between teachers, to support the work of less experienced teachers.

The subsequent Prime Ministerial Decree of 26 April 2020 (Official Gazette, 2020), recalling legislative decree no. 6 of 23 February 2020, further extended the suspension of face-to-face teaching activities for schools of all levels (article 1, paragraph k), reiterating once again that school leaders must activate teaching activities in distance mode, even for students with disabilities, who have specific needs (art. 1, paragraph $\mathrm{m}$ ).

As far as evaluation is concerned, the process must consider the situation in which it operates, the organizational difficulties, the situation of families, the needs of students to be supported in a time of uncertainty and insecurity. Thus, evaluating at a distance is an even more difficult action than normal. The complexity of this issue increases, if we consider, that even though there is an established field of technology-enhanced assessment, the assessment methods have not been previously used in primary and secondary education as much. Especially, in Italian scenario. For this reason, also, the essential starting point of distance assessment is represented by the regulatory dimension. The most important pre-Covid-19 references were:

- Presidential degree n. 122 del 22/06/2009 (p. 2), which states that the object of the evaluation concerns the learning process, the behaviour and the overall academic performance of the pupils. In addition, the evaluation has a formative purpose and contributes to the processes of self-assessment of the students themselves, to the improvement of knowledge levels and to the educational success.

- Legislative Decree no. 62 of 13/04/2017 (p.71), which reaffirms the formative and educational purpose of the evaluation and identifies the training process as the main object of the evaluation act.

- Note no. 388 of 17/03/2020 (p.7), issued during the Covid-19 pandemic, states that «It is equally necessary that constant evaluation activities be carried out, according to the principles of timeliness and transparency which, pursuant to current legislation, but even more than common sense of teaching, must inform any evaluation activity [...]. If the student is not immediately informed that he has made a mistake, what he has done wrong and why he has done wrong, the evaluation turns into a sanctioning rite, which has nothing to do with teaching, whatever the form in which it is exercised. But evaluation always has a role of enhancement, of indication to 
proceed with insights, with recoveries, consolidations, research, with a view to personalization that empowers the students, even more so in a situation like this».

The pre-Covid-19 regulatory framework has therefore demonstrated its value also in distance learning situations, as the focus in ministerial documents is and has always been formative evaluation; a type of evaluation consistent also with the pedagogy mediated by technologies. This article focuses on investigating the assessment practices in Italy during the Covid-19 Educational emergency and what we can learn from this experience. The article uses survey research to answer its main research questions.

\section{Research methodology and survey structure}

To understand the assessment practices and the potential changes in it, we have created a survey as a part of a large scale, multi-phase, mixed methods research (Eradze et al., 2021). This survey was developed following the phase 1 ethnographic study in teacher online communities (three Facebook groups) and points of interests. As already mentioned in the introduction, this study revealed that teacher peer communities have explored uncertainties and opportunities related to the re-organization of the assessment during the COVID-19 educational emergency.

The survey included a total of 39 items, including questions on demographic information, previous experience with digital tools, digital pedagogy competencies, as well as questions concerning participants' judgements and beliefs on help received by normative documents, schools, or online communities. The survey included further questions specifically concerning assessment. This set of items used the standard 1-5 Likert scale format. The online survey was launched for 3 weeks, from 23.12 .20 to 15.01 .21 , and distributed directly in the three online communities, after asking a permission to place the survey in the groups.

A total of 4314 teachers answered the survey. $92,7 \%$ of all participants $(n=3998)$ were women, $6 \%$ were men $(n=36)$ and $0,5 \%$ did not specify $(n=21)$. $43.3 \%$ of respondents were between 35 and 50 years old, $44.9 \%$ between 50 and 64 , whereas $10.5 \%$ were under 35 years old. Only $0.9 \%$ were 65 or older. Teachers' distribution by school order was as follows: $6,4 \%$ worked in kindergarten; $42.6 \%$ in primary school; $20.7 \%$ in lower secondary school; $20.7 \%$ in upper secondary school (Tab. 1). Since we focused on compulsory education, we excluded kindergarten teachers from the analysis; therefore, our sample consisted of 4036 unique entries. 
Tab. 1 - Distribution of survey respondents by school order. Absolute numbers $(N)$ and relative percentage on the total of respondents (\%) are shown

\begin{tabular}{lcc}
\hline School & $\mathrm{N}$ & $\%$ \\
\hline Kindergarten & 278 & $6,4 \%$ \\
Primary School & 1836 & $42,6 \%$ \\
Lower Secondary School & 891 & $20,7 \%$ \\
Upper Secondary School & 1290 & $29,9 \%$ \\
Missing & 19 & $0,4 \%$ \\
Total & 4314 & $100 \%$ \\
\hline
\end{tabular}

Statistical analysis was performed with SPSS27.0 software (IBM). Between-groups and pairwise comparisons were performed using parametric tests. All assumptions of equal variance were respected. Differences in nominal answer distribution were investigated using contingency tables with Pearson Chi-square test. Correlation analysis used parametric Pearson correlation (rho) test. All the results discussed, unless specified, were statistically significant at a $95 \%$ confidence interval $(\mathrm{p}<0.05)$. Mean values are presented \pm standard deviation.

\section{Results}

4.1 Teachers' beliefs about the importance of assessment before and after the pandemic

Two different items asked teachers to rate how much they consider assessment important when teaching in presence and how much they considered it important during the pandemic. In general. Teachers consider assessment when teaching in presence to be important, with a statistically significant difference between school orders (Tab. 2, One-way ANOVA, $\mathrm{F}=9.345, \mathrm{p}<0.001)$. Upper secondary school teachers considered assessment more important, on average $(\mathrm{M}=3,97 \pm 0,889)$, than lower secondary $(\mathrm{M}=3,89 \pm 0,907)$ and primary school teachers $(\mathrm{M}=3,82 \pm 0,982)$. When asked to rate the importance of assessment during the pandemic, there was still a significant difference between groups (One-way ANOVA, $\mathrm{F}=116,688$, $\mathrm{p}<0.001)$. Upper secondary school teachers still valued assessment more $(\mathrm{M}=3,43 \pm 1,015)$ than their colleagues in lower secondary school $(\mathrm{M}=3,12 \pm 1,049)$ and primary school $(\mathrm{M}=2,83 \pm 1,152)$. All groups rated the importance of assessment significantly less during the pandemic (Tab. 2) compared to assessment in presence. 
Education Sciences \& Society, 2/2021 ISSN 2038-9442, ISSNe 2284-015X

Tab. 2 - Teachers' beliefs about importance of assessment before and during the pandemic

\begin{tabular}{|c|c|c|c|c|c|c|}
\hline $\begin{array}{l}\text { Importance of } \\
\text { assessment: }\end{array}$ & School order & $\mathrm{N}$ & Mean & $\begin{array}{l}\text { Std. } \\
\text { Dev. }\end{array}$ & Test (F) & $p$-value \\
\hline \multirow[t]{3}{*}{ In presence } & Primary & 1824 & 3,82 & 0,982 & 9,345 & $<0,001^{\star *}$ \\
\hline & $\begin{array}{l}\text { Lower } \\
\text { Secondary }\end{array}$ & 881 & 3,89 & 0,907 & & \\
\hline & $\begin{array}{l}\text { Upper } \\
\text { Secondary }\end{array}$ & 1286 & 3,97 & 0,889 & & \\
\hline \multirow[t]{4}{*}{ During pandemic } & Primary & 1819 & 2,83 & 1,152 & 116,688 & $<0,001^{\star *}$ \\
\hline & $\begin{array}{l}\text { Lower } \\
\text { Secondary }\end{array}$ & 886 & 3,12 & 1,049 & & \\
\hline & $\begin{array}{l}\text { Upper } \\
\text { Secondary }\end{array}$ & 1276 & 3,43 & 1,015 & & \\
\hline & School order & $\mathrm{N}$ & $\begin{array}{l}\text { Mean } \\
\text { difference }\end{array}$ & $\begin{array}{l}\text { Std. } \\
\text { Dev }\end{array}$ & Test ( $t)$ & $p$-value \\
\hline \multirow{3}{*}{$\begin{array}{l}\text { Difference } \\
\text { before/during } \\
\text { pandemic }\end{array}$} & Primary & 1808 & $-0,989$ & 1,098 & $-38,316$ & $<0,001^{\star \star}$ \\
\hline & $\begin{array}{l}\text { Lower } \\
\text { Secondary }\end{array}$ & 876 & $-0,767$ & 0,980 & $-23,166$ & $<0,001^{\star *}$ \\
\hline & $\begin{array}{l}\text { Upper } \\
\text { Secondary }\end{array}$ & 1273 & $-0,530$ & 0,950 & $-19,905$ & $<0,001^{\star *}$ \\
\hline
\end{tabular}

\subsection{Use of assessment techniques before the pandemic}

We asked teachers to judge their use of seven assessment techniques before the pandemic using 1-5 Likert scales. Primary school teachers privileged, in order from most-used to less-used methods, individual oral examinations $(\mathrm{M}=3,14 \pm 1,269)$, closed-ended questions $(\mathrm{M}=3,13 \pm 1,108)$, problem solving $(\mathrm{M}=3,04 \pm 1,084)$, group oral examinations $(\mathrm{M}=3,02 \pm 1,271)$, open-ended questions $(\mathrm{M}=2,99 \pm 1,079)$ and, less prevalently, product-based $(\mathrm{M}=2,48 \pm 1,244)$ and semi-structured $(\mathrm{M}=2,38 \pm 1,156)$ tests. Lower secondary school teachers similarly favoured, in descending order, individual oral examinations ( $M=3,50 \pm 1,195)$, open-ended questions ( $M=3,34 \pm 1,049)$, closedended questions $(\mathrm{M}=3,31 \pm 1,070)$, products $(\mathrm{M}=3,09 \pm 1,250)$, problem solving $(\mathrm{M}=2,93 \pm 1,164)$, semi-structured $(\mathrm{M}=2,91 \pm 1,242)$, and group oral examinations $(\mathrm{M}=2,85 \pm 1,286)$. Upper secondary school teachers used, in descending order, individual oral examination $(\mathrm{M}=3,67 \pm 1,179)$, followed by 
open-ended questions $(\mathrm{M}=3,40 \pm 1,061)$, closed-ended questions $(\mathrm{M}=3,19 \pm 1,119)$, products $(\mathrm{M}=3,03 \pm 1,239)$, problem solving $(\mathrm{M}=3,02 \pm 1,194)$, semi-structured tests $(\mathrm{M}=3,01 \pm 1,233)$, and, less prevalently, group oral examinations $(\mathrm{M}=2,66 \pm 1,301)$.

When comparing pre-pandemic assessment habits of primary and secondary school teachers (Tab. 2), we found significant differences in the use of openended questions (One-way ANOVA, $\mathrm{F}=65,891, \mathrm{p}<0.001$ ), semi-structured tests (One-way ANOVA, $\mathrm{F}=101,060, \mathrm{p}<0.001$ ), closed-ended questions (One-way ANOVA, $\mathrm{F}=7,388, \mathrm{p}=0.001$ ), products (One-way ANOVA, $\mathrm{F}=88,645$, $\mathrm{p}<0.001$ ), individual oral examinations (One-way ANOVA, $\mathrm{F}=70,610$, $\mathrm{p}<0.001$ ), and group oral examinations (One-way ANOVA, $\mathrm{F}=26,808$, $\mathrm{p}<0.001)$. In all but the latter case, average usage was higher for secondary school teachers (both upper and lower) than primary school teachers.

Tab. 4 - Assessment techniques before the pandemic

\begin{tabular}{|c|c|c|c|c|c|c|}
\hline $\begin{array}{l}\text { Assessment } \\
\text { method }\end{array}$ & School order & $\mathrm{N}$ & Mean & $\begin{array}{l}\text { Std. } \\
\text { Dev. }\end{array}$ & Test (F) & $p$-value \\
\hline \multirow[t]{3}{*}{ Problem Solving } & Primary & 1528 & 3,04 & 1,084 & 2,527 & 0,80 \\
\hline & Lower Secondary & 746 & 2,93 & 1,164 & & \\
\hline & Upper Secondary & 1055 & 3,02 & 1,194 & & \\
\hline \multirow{3}{*}{$\begin{array}{l}\text { Closed-ended } \\
\text { questions }\end{array}$} & Primary & 1681 & 3,13 & 1,108 & 7,388 & $0,001^{*}$ \\
\hline & Lower Secondary & 817 & 3,31 & 1,070 & & \\
\hline & Upper Secondary & 1149 & 3,19 & 1,119 & & \\
\hline \multirow{3}{*}{$\begin{array}{l}\text { Open-ended } \\
\text { questions }\end{array}$} & Primary & 1567 & 2,99 & 1,079 & 65,891 & $<0,001^{*}$ \\
\hline & Lower Secondary & 799 & 3,34 & 1,049 & & \\
\hline & Upper Secondary & 1157 & 3,40 & 1,061 & & \\
\hline \multirow[t]{3}{*}{ Semi-structured } & Primary & 1491 & 2,38 & 1,156 & 101,060 & $<0,001^{*}$ \\
\hline & Lower Secondary & 767 & 2,91 & 1,242 & & \\
\hline & Upper Secondary & 1136 & 3,01 & 1,233 & & \\
\hline \multirow[t]{2}{*}{ Products } & Primary & 1514 & 2,48 & 1,244 & 88,645 & $<0,001^{*}$ \\
\hline & Lower Secondary & 792 & 3,09 & 1,250 & & \\
\hline
\end{tabular}




\begin{tabular}{lllllll} 
& Upper Secondary & 1148 & 3,03 & 1,239 & & \\
Individual & Primary & 1667 & 3,14 & 1,269 & 70,610 & $<0,001^{*}$ \\
Examination & Lower Secondary & 838 & 3,50 & 1,195 & & \\
& Upper Secondary & 1225 & 3,67 & 1,179 & & \\
Group Examination & Primary & 1602 & 3,02 & 1,271 & 26,808 & $<0,001^{*}$ \\
& Lower Secondary & 789 & 2,85 & 1,286 & & \\
& Upper Secondary & 1141 & 2,66 & 1,301 & & \\
\cline { 2 - 4 } & & & &
\end{tabular}

\subsection{Reorganisation of assessment during the pandemic}

We asked teachers to rate their use of the same seven assessment tools during the pandemic and compared these results with the pre-pandemic averages (Tab. 5). Across all school orders, teachers significantly decreased the use of individual oral examinations, open-ended questions, problem solving and semi-structured tests across all school orders. The use of group oral examinations significantly decreased in primary and lower secondary school but did not change in upper secondary school. Use of product-based tests did not change significantly during the pandemic. The use of closed-ended questions did not change significantly in primary schools but was the only assessment tool that showed a significant increase in lower and upper secondary schools.

Tab. 5 - Change in assessment practices during COVID / before COVID

\begin{tabular}{|c|c|c|c|c|c|c|}
\hline $\begin{array}{l}\text { Assessment } \\
\text { method }\end{array}$ & School order & $\mathrm{N}$ & $\begin{array}{l}\text { Before } \\
\text { Covid } \\
\text { Mean (SD) }\end{array}$ & $\begin{array}{l}\text { During } \\
\text { Covid } \\
\text { Mean (SD) }\end{array}$ & $\begin{array}{l}\text { Paired } \\
\text { samples } \\
\text { test }(t)\end{array}$ & $\begin{array}{l}\text { Sig. (2- } \\
\text { tailed) }\end{array}$ \\
\hline \multirow[t]{3}{*}{ Problem Solving } & Primary & 1333 & $3,07(1,058)$ & $2,69(1,118)$ & $-15,536$ &, $000^{* *}$ \\
\hline & $\begin{array}{l}\text { Lower } \\
\text { Secondary }\end{array}$ & 672 & $2,97(1,149)$ & $2,79(1,166)$ & $-5,177$ &, 000 ** \\
\hline & $\begin{array}{l}\text { Upper } \\
\text { Secondary }\end{array}$ & 966 & $3,07(1,118)$ & $2,86(1,170)$ & $-8,278$ &, $000 * \star$ \\
\hline \multirow{2}{*}{$\begin{array}{l}\text { Closed-ended } \\
\text { questions }\end{array}$} & Primary & 1530 & $3,16(1,086)$ & $3,14(1,162)$ & $-1,007$ & ,314 \\
\hline & $\begin{array}{l}\text { Lower } \\
\text { Secondary }\end{array}$ & 772 & $3,33(1,073)$ & $3,40(1,127)$ & 2,063 & ,039* \\
\hline
\end{tabular}




\begin{tabular}{|c|c|c|c|c|c|c|}
\hline & $\begin{array}{l}\text { Upper } \\
\text { Secondary }\end{array}$ & 1085 & $3,21(1,112)$ & $3,28(1,186)$ & 1084 &, $018^{*}$ \\
\hline \multirow{3}{*}{$\begin{array}{l}\text { Open-ended } \\
\text { questions }\end{array}$} & Primary & 1391 & $3,03(1,059)$ & $2,77(1,121)$ & $-10,113$ &, 000 ** \\
\hline & $\begin{array}{l}\text { Lower } \\
\text { Secondary }\end{array}$ & 737 & $3,36(1,038)$ & $3,19(1,099)$ & $-5,219$ &, 000 ** \\
\hline & $\begin{array}{l}\text { Upper } \\
\text { Secondary }\end{array}$ & 1071 & $3,43(1,039)$ & $3,26(1,111)$ & $-6,115$ &, 000 ** \\
\hline \multirow[t]{3}{*}{ Semi structured } & Primary & 1321 & $2,40(1,149)$ & $2,24(1,148)$ & $-5,880$ &, $000^{* *}$ \\
\hline & $\begin{array}{l}\text { Lower } \\
\text { Secondary }\end{array}$ & 705 & $2,93(1,226)$ & $2,83(1,233)$ & $-2,519$ &, $012^{*}$ \\
\hline & $\begin{array}{l}\text { Upper } \\
\text { Secondary }\end{array}$ & 1060 & $3,02(1,232)$ & $2,94(1,226)$ & 1059 &, $006^{*}$ \\
\hline \multirow[t]{3}{*}{ Products } & Primary & 1366 & $2,51(1,238)$ & $2,48(1,245)$ & $-1,091$ & ,276 \\
\hline & $\begin{array}{l}\text { Lower } \\
\text { Secondary }\end{array}$ & 740 & $3,10(1,247)$ & $3,13(1,272)$ & 0,940 & ,348 \\
\hline & $\begin{array}{l}\text { Upper } \\
\text { Secondary }\end{array}$ & 1064 & $3,04(1,237)$ & $3,09(1,246)$ & 1,884 &, 060 \\
\hline \multirow{3}{*}{$\begin{array}{l}\text { Individual } \\
\text { Examination }\end{array}$} & Primary & 1483 & $3,18(1,252)$ & $2,88(1,315)$ & $-10,265$ &, $000^{\star \star}$ \\
\hline & $\begin{array}{l}\text { Lower } \\
\text { Secondary }\end{array}$ & 783 & $3,51(1,191)$ & $3,22(1,265)$ & $-7,386$ &, 000 ** \\
\hline & $\begin{array}{l}\text { Upper } \\
\text { Secondary }\end{array}$ & 1152 & $3,68(1,170)$ & $3,57(1,203)$ & $-4,135$ &, $000^{* *}$ \\
\hline \multirow{3}{*}{$\begin{array}{l}\text { Group } \\
\text { Examination }\end{array}$} & Primary & 1417 & $3,05(1,269)$ & $2,83(1,345)$ & $-7,484$ &, 000 ** \\
\hline & $\begin{array}{l}\text { Lower } \\
\text { Secondary }\end{array}$ & 718 & $2,89(1,263)$ & $2,61(1,344)$ & $-6,806$ &, $000^{* *}$ \\
\hline & $\begin{array}{l}\text { Upper } \\
\text { Secondary }\end{array}$ & 1039 & $2,67(1,285)$ & $2,64(1,338)$ &,- 973 & ,331 \\
\hline
\end{tabular}

488 


\subsection{Remote-only assessment methods}

Finally, we asked teachers to assess their use of remote-specific assessment tools (Tab. 6). On average, teachers used video calls quite often as a method of assessment, without significant differences across school orders (primary school $\mathrm{M}=3,29 \pm 1,411$; lower secondary school $\mathrm{M}=3,36 \pm 1,442$; upper secondary school $\mathrm{M}=3,32 \pm 1,510$; One-way ANOVA, $\mathrm{F}=0,641, \mathrm{p}<0.527$ ). Online exercises were also often utilized, albeit with significant differences between groups (primary school $\mathrm{M}=3,17 \pm 1,280$; lower secondary school $\mathrm{M}=3,38 \pm 1,215$; upper secondary school $\mathrm{M}=3,25 \pm 1,263$; One-way ANOVA, $\mathrm{F}=7,209$, $\mathrm{p}<0.001$ ). Finally, we asked teachers if they used assessment tools not included in the survey. The mean of the answer was very low (primary school $\mathrm{M}=1,36 \pm 0,911$; lower secondary school $\mathrm{M}=1,36 \pm 0,876$; upper secondary school $\mathrm{M}=1,25 \pm 0,762$; One-way ANOVA, $\mathrm{F}=2,076, \mathrm{p}=0.126$ ) thus indicating that our survey included the most common assessment methods used by teachers.

Tab. 6 - Distance learning-specific assessment methods

\begin{tabular}{|c|c|c|c|c|c|c|}
\hline $\begin{array}{l}\text { Assessment } \\
\text { method }\end{array}$ & $\begin{array}{l}\text { School } \\
\text { order }\end{array}$ & $\mathrm{N}$ & Mean & Std. Dev. & Test (F) & $\mathrm{p}$-value \\
\hline \multirow{3}{*}{$\begin{array}{l}\text { Online } \\
\text { exercises }\end{array}$} & Primary & 1530 & 3,17 & 1,280 & 7,209 &, $001^{*}$ \\
\hline & $\begin{array}{l}\text { Lower } \\
\text { Secondary }\end{array}$ & 779 & 3,38 & 1,215 & & \\
\hline & $\begin{array}{l}\text { Upper } \\
\text { Secondary }\end{array}$ & 1096 & 3,25 & 1,263 & & \\
\hline \multirow[t]{3}{*}{ Video calls } & Primary & 1478 & 3,29 & 1,411 & 0,641 &, 527 \\
\hline & $\begin{array}{l}\text { Lower } \\
\text { Secondary }\end{array}$ & 759 & 3,36 & 1,442 & & \\
\hline & $\begin{array}{l}\text { Upper } \\
\text { Secondary }\end{array}$ & 1086 & 3,32 & 1,510 & & \\
\hline \multirow{3}{*}{$\begin{array}{l}\text { None of the } \\
\text { above }\end{array}$} & Primary & 406 & 1,36 & 911 & 2,076 & ,126 \\
\hline & $\begin{array}{l}\text { Lower } \\
\text { Secondary }\end{array}$ & 247 & 1,36 & 876 & & \\
\hline & $\begin{array}{l}\text { Upper } \\
\text { Secondary }\end{array}$ & 356 & 1,25 & ,762 & & \\
\hline
\end{tabular}




\section{Conclusions}

Before the pandemic, teachers in all school orders examined considered, on average, assessment as very important; in particular, the higher the school order, the higher teachers tend to value assessment higher. Our data also suggest that there existed significant differences in the assessment habits in different school orders even before the pandemic. Individual examinations were the most common assessment technique across all school orders, and its use was higher in secondary and, especially, upper secondary school. Conversely, group examinations were most common in primary school and progressively less employed in secondary school, possibly indicating a progressive passage from group to individual interrogation as the learners grow up. Quizzes employing open and closed questions were more prevalent in secondary school than in primary, as is the case for semi-structured tests and product-based tests. The only assessment method that didn't show an upward or downward trend with different school orders was problem-based tests.

The Covid pandemic didn't subvert the existing differences concerning the importance attributed to assessment in different school orders (if anything, it seem to have exacerbated existing differences, see Tab. 2). What is striking, however, is that the importance that teachers at all school orders give to assessment has drastically diminished during the pandemic. The effect is particularly dramatic in primary school (Tab. 2). When observed in this perspective, it is unsurprising that most methods of assessment examined were reportedly less employed during the emergency (Tab. 5). Still, our analysis highlights important differences in the way teachers rearranged their modes of assessment. Individual examinations were the most common assessment techniques across all school orders before COVID (Tab. 4). Its usage diminished drastically during the pandemic, and in primary school it was surpassed by closed questions quizzes as the most prevalent method of assessment. Group examinations were used less frequently during the pandemic in primary and lower secondary schools. Taken together, these data suggest a reduction in the use of examination as assessment method during the pandemic. Furthermore, tests that used problem solving as the main method of assessment, as well as open-ended question tests and semi-structured tests, diminished significantly in all school orders during the pandemic. (Tab. 5). The two assessment methods that differed from this trend were product-based assessment and closed question quizzes. The first, which was rather scarcely used in primary school and had an average use in secondary school, didn't change significantly in used during the pandemic. This might be since productbased tasks can be realized asynchronously, a mode of work that is common in distance learning. Furthermore, the use of closed question quizzes didn't 
change significantly in primary school, and instead were the only assessment method that saw a significant increase during the pandemic, in both lower and upper secondary school (Tab. 5). Finally, during the pandemic teachers resorted significantly on online exercises and video-calls (Tab. 6). Overall, our study shows that, at least in the Italian case that we investigated, a significant reorganization of assessment happened during the COVID pandemic emergency. In all school orders, teachers perceived a reduction in the importance of assessment during the pandemic and used traditional assessment techniques significantly less than when teaching in presence. However, the change was not the same for different school orders and different assessment methods, with oral examinations diminishing dramatically and an increased use of closed-question quizzes.

\section{References}

Albó L., Beardsley M., Martínez-Moreno J., Santos P. and Hernández-Leo, D. (2020). Emergency remote teaching: Capturing teacher experiences in Spain with SELFIE. European Conference on Technology Enhanced Learning, 318-331.

Beardsley M., Albó L., Aragón P. and Hernández-Leo, D. (2021). Emergency education effects on teacher abilities and motivation to use digital technologies. British Journal of Educational Technology, 52(4): 1455-1477. DOI: 10.1111/bjet.13101.

Bozkurt A., Jung I., Xiao J., Vladimirschi V., Schuwer R., Egorov G., Lambert S., AlFreih M., Pete J. and Olcott Jr D. (2020). A global outlook to the interruption of education due to COVID-19 Pandemic: Navigating in a time of uncertainty and crisis. Asian Journal of Distance Education, 15(1): 1-126. DOI: 10.5281/zenodo.3878572.

Eradze M., Bardone E. and Dipace A. (2021). Theorising on Covid-19 Educational Emergency: Magnifying Glasses for the Field of Educational Technology. Learning, Media and Technology. DOI: 10.1080/17439884.2021.1961802.

Fullan M., Quinn J., Drummy M. and Gardner M. (2020). Education reimagined: The future of learning. A Collaborative Position Paper between New Pedagogies of Deep Learning and Microsoft Education. [Online] available at: https://edudownloads.azureedge.net/msdownloads/Microsoft-

EducationReimagined-Paper.pdf [accessed on 5/11/2021].

Gamage K.A.A., de Silva E.K. and Gunawardhana N. (2020). Online Delivery and Assessment during COVID-19: Safeguarding Academic Integrity. Education Sciences 2020, 10(11): 301. DOI: 10.3390/EDUCSCI10110301.

Giovannella C., Passarelli M., Alkhafaji A.S.A. and Negrón A.P.P. (2021). A comparative study on the effects of the COVID-19 pandemic on three different national university learning ecosystems as bases to derive a Model for the Attitude to get Engaged in Technological Innovation (MAETI). Interaction Design and 
Architecture(s) Journal - IxD\&A, 47: 167-190. DOI: 10.1001/jamacardio.2020.1286.

Harlen W. (2007). Assessment of learning. Sage. DOI: 10.4135/9781446214695.

Hodges C., Moore S., Lockee B., Trust T. and Bond A. (2020). The difference between emergency remote teaching and online learning. Educause Review, 27.

Johnson T. (2020). Participant observation of a teachers' online community during the COVID-19 pandemic in Georgia. The university of Tartu.

Johnson T., Eradze M. and Kobakhidze M.N. (2022). Finding a silver lining in the COVID-19 pandemic: Participant observation of a teachers' online community in Georgia. In: Loureiro M.J., Loureiro A. and Gerber H.R., eds., Global Education and the Impact of Institutional Policies on Educational Technologies (p. In print).

Luik P., Lepp M. (2021). Changes in activity and content of messages of an Estonian Facebook group during transition to distance learning at the beginning of the COVID-19 pandemic. Journal of Computer Assisted Learning. DOI: 10.1111/jcal.12602.

Rapanta C., Botturi L., Goodyear P., Guàrdia L. and Koole M. (2021). Balancing Technology, Pedagogy and the New Normal: Post-pandemic Challenges for Higher Education. Postdigital Science and Education. DOI: 10.1007/s42438-021-00249-1. Wiliam D. (2011). What is assessment for learning? Studies in Educational Evaluation, 37(1): 3-14. DOI: 10.1016/j.stueduc.2011.03.001. 